\title{
Duplication 8p Syndrome: Studies in a Family With a Reciprocal Translocation Between Chromosomes 8 and 12
}

\author{
H. MorenoFuenmayor, K.L. Meilinger, D.L. Rucknagel, H.L. Mohrenweiser, \\ and E. H. Y. Chu \\ Departments of Human Genetics and Internal Medicine, (Medical Genetics Division), The \\ University of Michigan, School of Medicine, Ann Arbor
}

\begin{abstract}
We report a family in which six individuals were carriers of a translocation between chromosomes 8 and 12 . The balanced carriers had a chromosome constitution: $46, \mathrm{XX}$ or $46, \mathrm{XY}, \mathrm{t}(8 ; 12)(021 ; \mathrm{p} 13)$. Six individuals in five generations were mentally retarded. Three of them were examined; their chromosome constitution was $46, \mathrm{XX}$ or $46, \mathrm{XY}, \operatorname{der}(12), \mathrm{t}(8 ; 12)(\mathrm{p} 21 ; \mathrm{p} 13)$; thus they had a duplication of 8 pter $\rightarrow 8 \mathrm{p} 21$ and possible deficiency of $12 \mathrm{pter} \rightarrow 12 \mathrm{p} 13$. The activities of the enzymes that are coded by genes on $8 p$ (glutathione reductase, GSR, E.C. 1.6.4.2.) and $12 \mathrm{p}$ (triosephosphate isomerase, TPI, E.C. 5.3.1.1.; lactate dehydrogenase-B, LDH-B, E.C. 1.1.1.27.; and glyceraldehyde-3-phosphate dehydrogenase, G3PD, E.C. 1.2.1.12.) were normal in these individuals. These findings helped in interpreting the position of the break points in the respective chromosomes. The phenotypic findings in our patients are discussed.

Segregation analysis indicates no significant variation from a $25 \%$ recurrence risk for each of the possible genotypes in the offspring of balanced carriers.
\end{abstract}

Key words: duplication/deficiency syndrome, familial translocation, recurrence risk, segregation ratio, multiple congenital anomalies/mental retardation (MCA/MR) syndrome

\section{INTRODUCTION}

Several balanced and unbalanced carriers of a chromosome translocation $8 ; 12$ were ascertained through the examination of a mentally retarded 23-year-old woman, whose brother, the propositus, required genetic counselling. The retarded sister of the prospositus, two of her cousins, and possibly three other mentally retarded individuals in this family were shown to have a duplication of a portion of the short arm of chromosome 8 , and were likely deficient for the terminal segment of $12 \mathrm{p}$. We report the phenotypic findings in these individuals and compare them to those of previously reported cases. An attempt was made to locate more precisely the breakpoints by assaying the activities of the enzymes whose loci are known to be located on $8 p$ and $12 p$ for evidence of gene dosage effects.

Received for publication June 3, 1980; revision received July 18, 1980.

Address reprints requests to $H$. MorenoFuenmayor, MD, Unidad de Genética Médica, Hospital Universitario, Apartado Postal 1349 (Las Playitas) Maracaibo, Venezuela. 

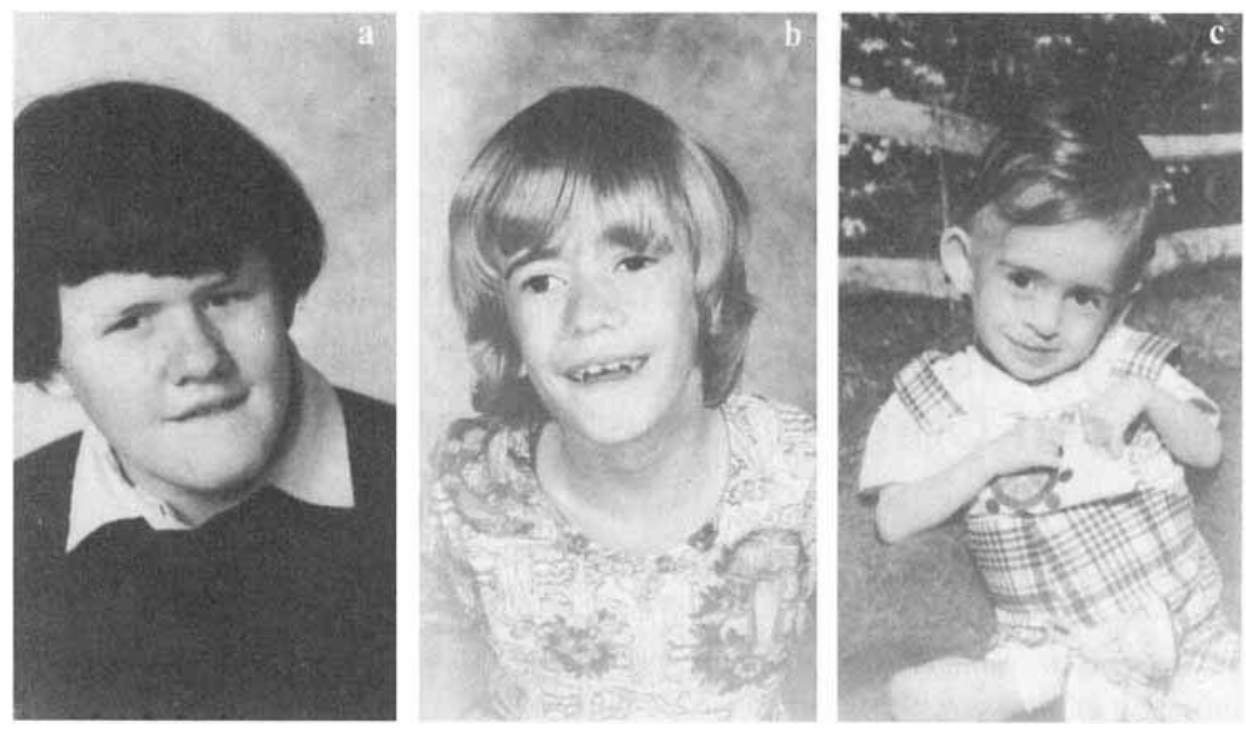

Fig. 1. a: Patient 1, sister of the propositus. b: Patient 2. c: Patient 3.

\section{REPORTS OF PATIENTS}

\section{Patient 1}

MW 121056(Fig. 1a; V-2 in Fig. 2), sister of the propositus, a 23-year-old woman, was the product of an uneventful pregnancy and delivery, born to a 23-year-old gravida 2 mother who had had a previous spontaneous abortion. Since birth she had been hypoactive and had had feeding difficulties. Strabismus was evident. She had an atrial septal defect and electrocardiogram (ECG) signs of atrioventricular block, complicated later in infancy with left atrial enlargement, and left ventricular hypertrophy. Mental retardation (MR) was evident since early infancy. Her IQ (Stanford-Binet) was estimated to be around 20 at 23 years. Middle-ear infections were frequent during infancy. She also had a "square" face, prominent glabella, antimongoloid slant of the palpebral fissures, bulbous nose, open mouth with malocclusion, highly arched palate, prominent mandible, prominent and malformed ears, and low posterior hairline. Normal breast development, mild scoliosis, and holosystolic murmur were present. The hands were slender and short with tapering of the fingers and hyperextensible middle phalanges. The patient had rockerbottom feet with limited movement at ankles and overlapping first and fifth toes. There was constant flexion at most major joints.

\section{Patients 2 and 3}

MP 072369, female, age 11 years, and RG 031975, male, age five years (Fig. $1 \mathrm{~b}, \mathrm{c})$. Both of these similarly affected half-sibs (V-12 and V-13 in Fig. 2) had MR, the same abnormal facial appearance as patient 1 , and semiflexion at the major joints. V-12 had clinodactyly of the left fifth finger; club feet had been corrected previously. Atrial and ventricular septal defects were present. V.13 had bilateral clinodactyly, a pectus excavatum, a diaphragmatic hernia, cleft lip and palate, and cryptorchidism. This child had 


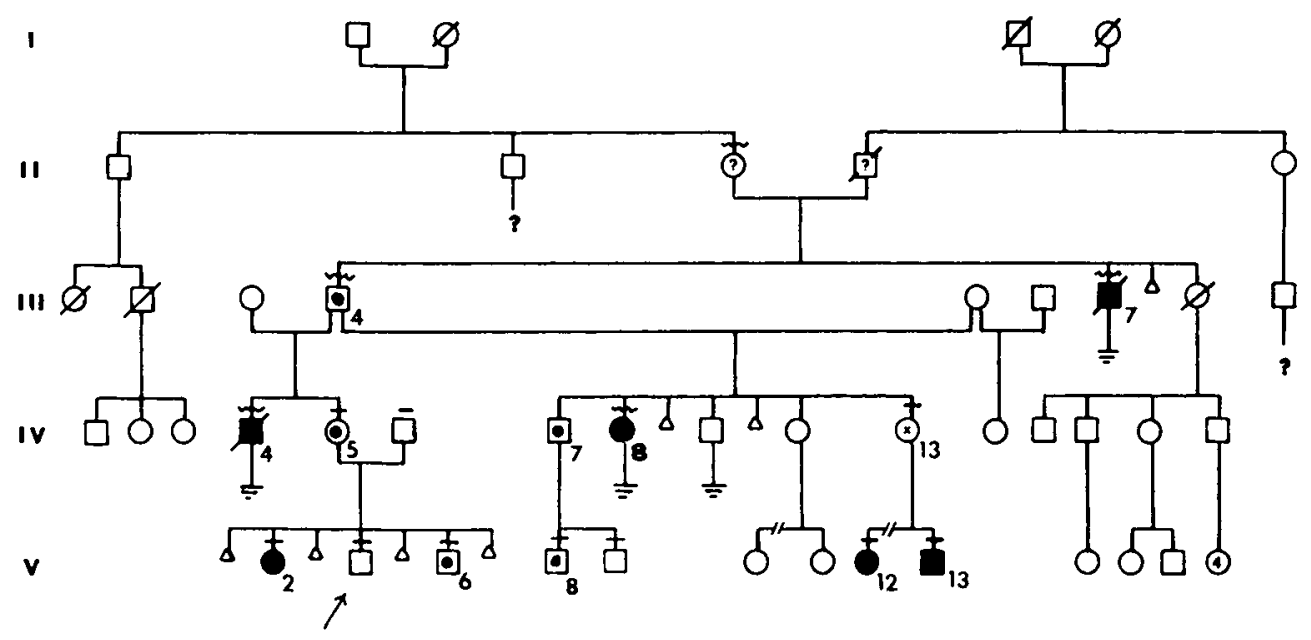

Fig. 2. Pedigree. Affected individuals are denoted as black symbols. Karyotyped balanced carriers as dots inside the symbol. $X$ = obligate carriers. ? = information unknown. Personally examined individuals are identified with a straight line above the symbol. Photograph examined with a wavy line. "Grounded" symbol represents lack of offspring.

no evidence of heart disease. Middle-ear infections were frequent during infancy. EEGs were not specifically abnormal. A CAT scan was normal in V-12; that of V-13 was compatible with dilatation of the posterior horns of the lateral ventricles. These individuals had the same chromosome defect as the sister of the propositus.

\section{Patients 4 to 6}

Three other family members were known to be mentally retarded (III-7, IV-4, and IV-8 in Fig. 2). Photographs of these individuals suggested that they had the same clinical syndrome, but they were not examined.

\section{DERMATOGLYPHIC STUDIES}

The palmar dermatoglyphics of the three patients examined were unusual and dissimilar from those of their parents. These findings are depicted in Table I. V-2 had a simian crease in the left hand. V-12 had a double triradius $a$, interdigital loops in the second and third spaces of the right hand, and bilateral absence of the $c$ triradii. V-13 had a bilateral Sydney line. The triradii $b$ and $c$ appeared too close together in patients 1 and 3 , which may account for the narrow atd angle in all three patients (Table I).

\section{CHROMOSOME STUDIES}

Cytogenetic analysis was performed in ten individuals; six phenotypically normal individuals (III-4, IV-5, IV-7, IV-13, V-6, and V-8; Fig.2) were balanced carriers of a translocation 8;12(8pter $\rightarrow 8$ p21::12p13 $\rightarrow 12$ pter; 12pter $\rightarrow 12$ p13::8p21 $\rightarrow 8$ pter) (Fig. 3). All three of the six mentally retarded individuals who were examined (V-2, V-12, and V-13) were found to have a duplication of the segment 8 pter $\rightarrow 8 \mathrm{p} 21$, and a possible deletion of 
TABLE I. Palmar Dermatoglyphics

\begin{tabular}{lllccc}
\hline \multicolumn{2}{c}{ Digital patterns } & $\begin{array}{c}\text { Total } \\
\text { ridge count }\end{array}$ & $\begin{array}{c}\text { atd } \\
\text { Anglea }\end{array}$ & Palmar patterns \\
\hline Patient 1 & $\mathrm{UL}^{1} \mathrm{~A}^{2} \mathrm{~A}^{3} \mathrm{~A}^{4} \mathrm{~A}^{5}$ & $\mathrm{UL}^{1} \mathrm{~A}^{2} \mathrm{~A}^{3} \mathrm{~A}^{4} \mathrm{~A}^{5}$ & 28 & $40 / 45$ & $\mathrm{H}: \mathrm{Ac}^{\mathrm{c}} / \mathrm{A}^{\mathrm{c}}$ T: $0 / 0$ \\
Patient 2 & $\mathrm{UL}^{1} \mathrm{~W}^{2} \mathrm{~W}^{3} \mathrm{~W}^{4} \mathrm{UL}^{5}$ & $\mathrm{UL}^{1} \mathrm{~W}^{2} \mathrm{~W}^{3} \mathrm{UL}^{4} \mathrm{UL}^{5}$ & 147 & $44 / 47$ & $\mathrm{H}: \mathrm{A}^{\mathrm{c}} / \mathrm{A}^{\mathrm{c}} \mathrm{T}: 0 / 0$ \\
Patient 3 & $\mathrm{UL}^{1} \mathrm{UL}^{2} \mathrm{UL}^{3} \mathrm{~W}^{4} \mathrm{UL}^{5}$ & $\mathrm{UL}^{1} \mathrm{~W}^{2} \mathrm{UL}^{3} \mathrm{~W}^{4} \mathrm{UL}^{5}$ & 105 & $35 / 43$ & $\mathrm{H}: \mathrm{A}^{\mathrm{u}} / \mathrm{A}^{\mathrm{u}}$ T: $: 0 / 0$
\end{tabular}

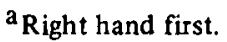

$\mathrm{H}=$ hypothenar; $\mathrm{T}=$ thenar.

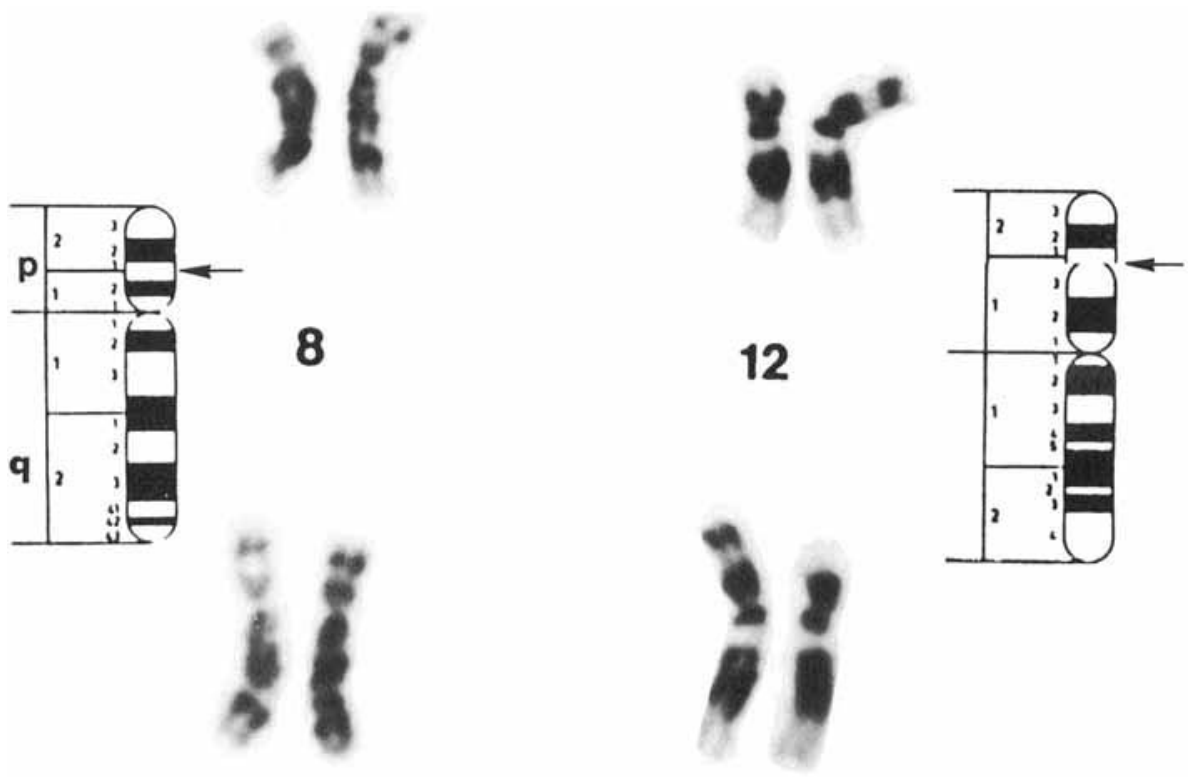

Fig. 3. Partial karyotypes of IV-5 (mother of the propositus, top) and V-2 (sister of the propositus, bottom). Arrows indicate the postulated position of the breakpoints in the chromosomal segments.

$12 \mathrm{pter} \rightarrow 12 \mathrm{p} 13$. Their karyotype designation was $46, \mathrm{XX}$ or $46, \mathrm{XY}, \operatorname{der}(12), \mathrm{t}(8 ; 12)(\mathrm{p} 12 ; \mathrm{p} 13)$ (Fig. 3). The other affected relatives were presumably similarly affected since the alternative cytogenetic abnormality, deletion $8 \mathrm{p}$, is most likely inviable.

\section{ENZYME ANALYSES}

In the affected persons and a control group we assayed the activities of three enzymes (triosephosphate isomerase, E.C. 5.3.1.1.; lactate dehydrogenase-B, E.C. 1.1.1.27.; glyceraldehyde-3-phosphate dehydrogenase, E.C. 1.2.1.12.) whose structural loci are known 
to be located on the distal band of the short arm of chromosome 12 [Serville et al, 1978; Rethoré et al, 1976; Bootsma and Ruddle, 1978; Law and Kao, 1979], and glutathione reductase, which has been mapped to the region p21 of chromosome 8 [de la Chapelle et al, 1976; Sinet et al, 1977; Magenis et al, 1978] ; previously published methods [Beutler, 1975; Fielek and Mohrenweiser, 1979] were used. The level of activity of each enzyme was normal in each of the two groups. The absence of a dosage effect for glutathione reductase in the unbalanced carriers (affected patients mean values, 1,293 $\mu \mathrm{mol} /$ $\mathrm{min} / \mathrm{gm}$ of hemoglobin versus controls, $1,317 \mu \mathrm{mol} / \mathrm{min} / \mathrm{gm}$ of hemoglobin) indicates that the breakpoint on band $8 \mathrm{p} 21$ for this translocation is distal to the gene for glutathione reductase. Similarly activity measurements of the three enzymes mapping on $12 \mathrm{p}$ (TPI patients, 103,400 versus controls, $120,000 \mu \mathrm{mol} / \mathrm{min} / \mathrm{gm}$ of hemoglobin; LDH-B, patients, 8,086 versus controls, $7,069 \mu \mathrm{mol} / \mathrm{min} / \mathrm{gm}$ of hemoglobin; G3PD patients, 3,811 versus controls, $3,428 \mu \mathrm{mol} / \mathrm{min} / \mathrm{gm}$ of hemoglobin) does not show loss of any activity, hence, the break must be distal to these loci on $12 \mathrm{p}$.

\section{DISCUSSION}

Clinical findings in our patients are summarized in Table II and compared with those of previously reported cases [Yanagisawa and Hiraoka, 1971; Yanagisawa, 1973; Rosenthal et al, 1973; Chiyo et al, 1975; Taylor et al, 1977; Mattei et al, 1980]; another patient has been mentioned in an abstract [Cowell et al, 1978]. A distinct phenotype seems due to duplication 8p; namely, MR, strabismus, palatal abnormalities, malformed ears, congenital heart disease, brain abnormalities (including dilatation of the lateral ventricles and/or absence of the corpus callosum), hyperextensible interphalangeal and metacarpophalangeal joints, and flexion contractures. Dermatoglyphic abnormalities include an excess of arches or whorls, simplification of creases in the palms, and a narrow atd angle; the feet and soles may be abnormal and toenails hypoplastic. A shortened lifespan may be expected in these patients; early death seems related to the severity of the cardiac defects, associated malformations or possibly diminished resistance to infections (two of our patients died of pneumonia). Phenotypic variability in some of our patients regarding the severity of the heart disease, the dermatoglyphic findings, and the presence of associated malformations such as cleft lip and palate, and diaphragmatic hernias, falls within the range expected in duplication/deficiency syndromes.

This family is also useful for making inferences regarding the reproductive outcome of balanced carriers. The recurrence risk for the unbalanced genotypes among the offspring of carriers of chromosomal translocations has been estimated to be between $8 \%$ and $15 \%$ [Lejeune et al, 1970]. In our family, among 24 pregnancies observed in the matings of the balanced carriers, the following resulted: 1) seven abortuses $(29 \%)$; 2 ) six mentally retarded individuals (25\%); at least six translocation carriers (25\%); at most, five cytogenetically normal individuals $(20 \%)$. Assuming that the abortuses had an $8 p$ deletion, the observed proportions of these four genotypes do not significantly differ from $25 \%$. Previously reported pedigrees with the duplication $8 \mathrm{p}$ syndrome [Yanagisawa and Hiraoka, 1971] gave similar results. A similar outcome has been reported for a $4 / 12$ translocation [Mortimer et al, 1980]. It follows, that segregation ratios may vary in the different forms of familial translocations and that selective mechanisms may act before or after fertilization to distort the theoretical ratios in some of them [Jacobs et al, 1970]. We suggest that, whenever possible, counselling of balanced carriers should be based on the observed segregation ratios within their families. 


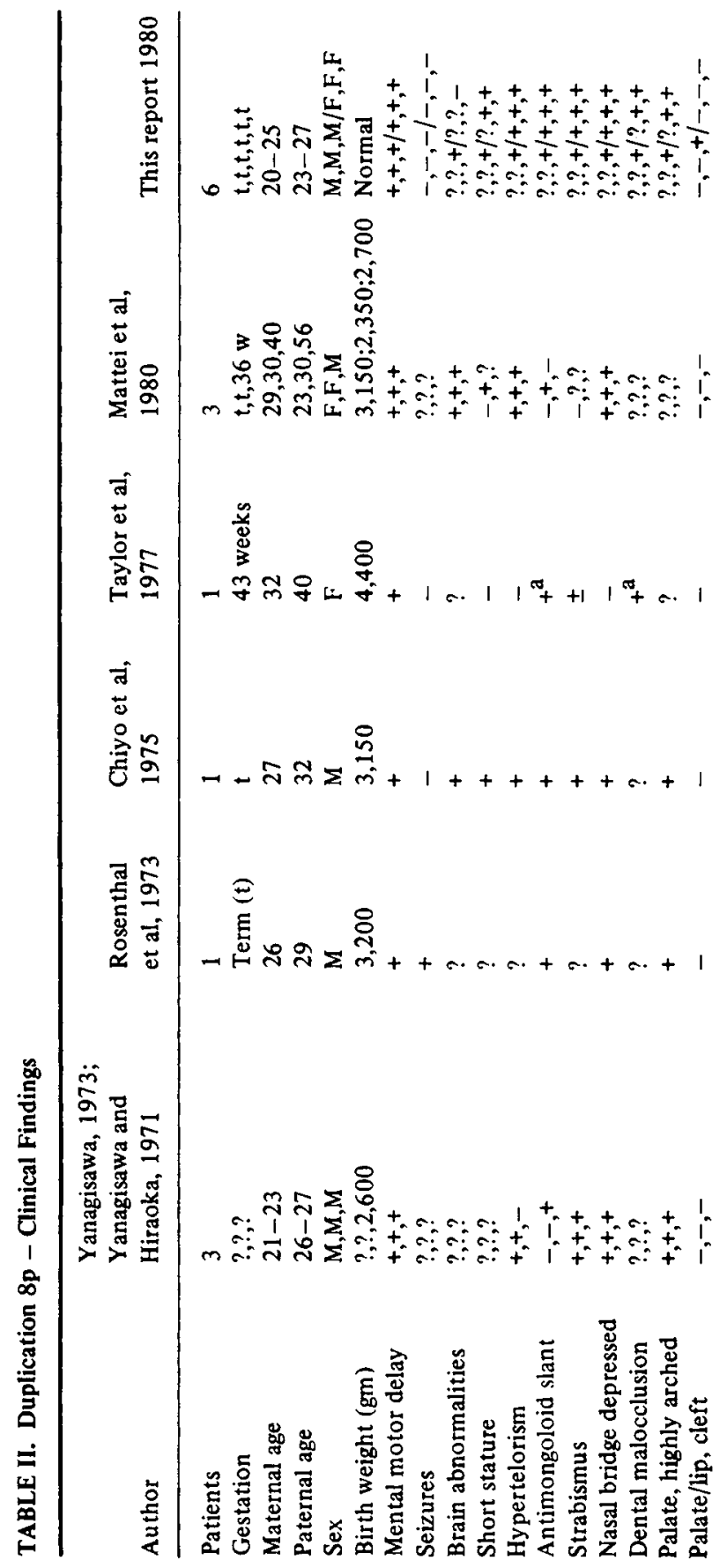




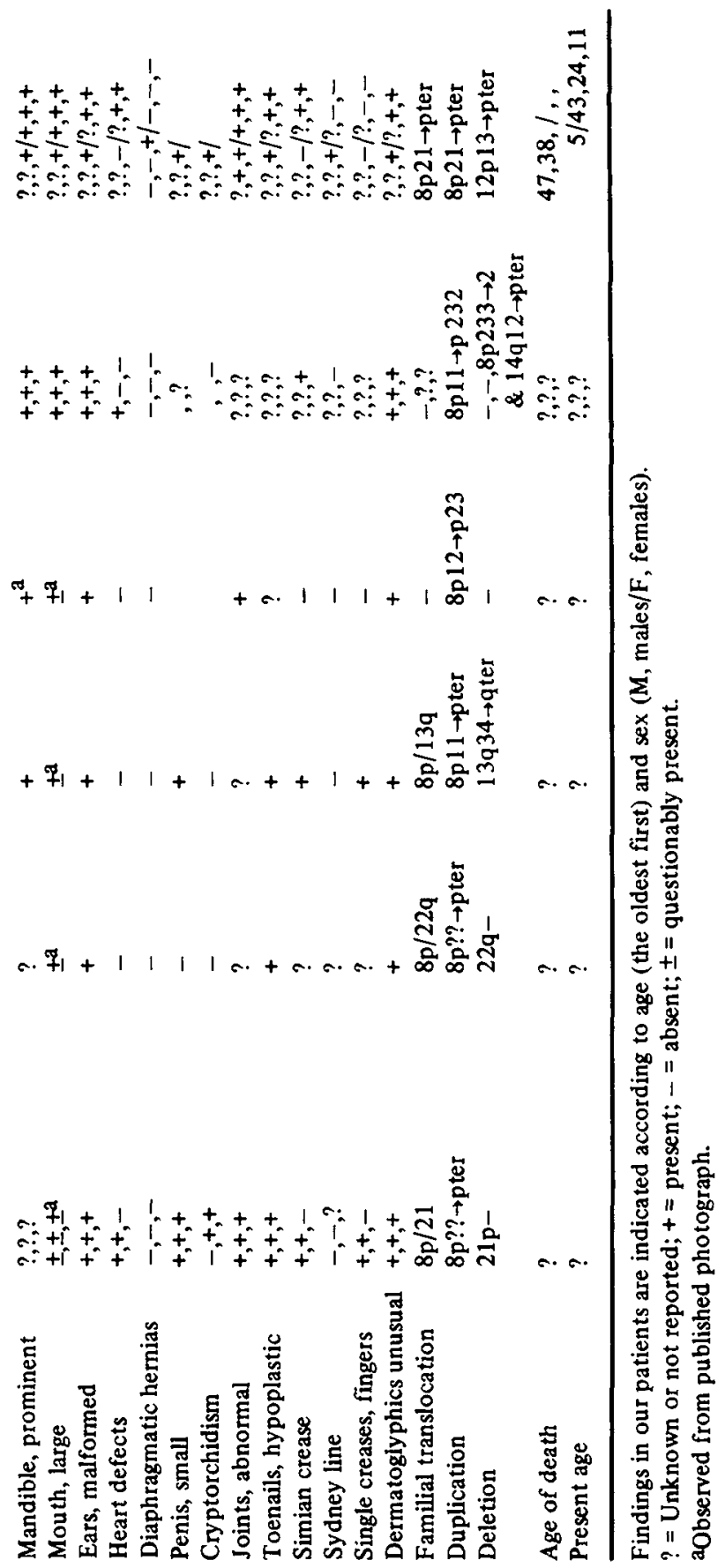




\section{ACK NOWLEDGMENTS}

We wish to thank Dr. J.V. Neel and Dr. R.P. Erickson for helpful comments, and Beverly Steinke for secretarial assistance. This work has been supported by a University of Zulia (Venezuela) postdoctoral training grant, whose recipient is Dr. Moreno, and the Medical Genetics Division of the Departments of Internal Medicine and Human Genetics, University of Michigan School of Medicine.

\section{REFERENCES}

Beutler E (1975): "Red Cell Metabolism: A Manual of Biochemical Methods," Ed 2. New York: Grune \& Stratton.

Bootsma D, Ruddle FH: Report of the committee on the genetic constitution of chromosomes $2,3,4,5$, $7,8,10,11$ and 12, human gene mapping (4), Winnipeg Conference. Cytogenet Cell Genet 22:74-91, 1978 .

de la Chapelle A, Icen A, Aula P, Leisti I, Turleau C, deGrouchy J: Mapping of the gene for glutathione reductase on chromosome 8. Ann Génét 19:253-256, 1976.

Chiyo H, Nakagome Y, Matsui I, Kuroki Y, Kobayashi H, Ono K: Two cases of 8p trisomy in one sibship. Clin Genet 7:328-333, 1975

Cowell HR, Casey PA, Paulson KM: Unusual cytogenctic aberrations in patients with multiple congenital anomalies, abstract. Am J Hum Genet 30:77 A, 1978.

Fielck S, Mohrenweiser HL: Erythrocyte enzyme deficiencies assessed with a miniature centrifugal analyzer. Clin Chem 25:384-388, 1979.

Jacobs PA, Aitken J, Frackiewicz A, Law P, Newton MS, Smith PG: The inheritance of translocations in man: Data from families ascertained through a balanced heterozygote. Ann Hum Genet (Lond) 34:119-136, 1970.

Law ML, Kao FT: Regional assignments of human genes TPI-1, GAPDH, LDHB, SHMT and PEPB on chromosome 12. Cy togenet Cell Genet 24:102-104, 1979.

Lejeune J, Dutrillaux B, deGrouchy J: Reciprocal translocations in human populations. A preliminary analysis. In Jacobs, Price, Law: "Pfizer Medical Monographs No. 5, Human Population Cytogenetics." Edinburgh: Edinburgh University Press, 1970.

Magenis RE, Reiss J, Bigley R, Chamberlain J, Lovrien E: Exclusion of glutathione reductase from $8 p$ ter $\rightarrow 8$ p 22 and localization to 8 p21. Cy togenet Cell Genet 22:446-448, 1978.

Mattei JF, Mattei MG, Ardissone JP, Coignet J, Giraud F: Clinical, enzyme and cy togenetic investigations in three new cases of trisomy 8 p. Hum Genet $53: 315-321,1980$.

Mortimer JG, Chewings WE, Gardner RJM: A further report on a kindred with cases of $4 \mathrm{p}$ trisomy and monosomy. Hum Hered 30:58-61, 1980.

Rethoré MO, Junien C, Malpeuch G, Bachehetti C, Tenconi F, Kaplan JC, de Romeuf J, Lejeune J: Localization du gène de la glyceraldehyde-3-phosphate dehydrogenasc (G3PD) sur le segment distal du bras court du chromosome 12. Ann Génét 19:140-142, 1976.

Rethoré MO, Kaplan JC, Junien C, Cruveiller J, Dutrillaux B, Aurias A, Carpentier S, Lafourcade J, Lejeune $\mathrm{J}$ : Augmentation de l'activité de LDH-B chez un garçon trisomique $12 \mathrm{p}$ par malségrégation d'une translocation maternelle $t(12 ; 14)(q 12 ; p 11)$. Ann Génét 18:81-87, 1976.

Rosenthal IM, Krmpotic F, Bocian M, Szego K: Trisomy of the short arm of chromosome 8: Association with translocation between chromosome 8 and $22: 46, X Y, 22-, t(8 p 22 q)+$. Clin Genet 4:507-516, 1973.

Serville F, Junien C, Kaplan JC, Grachet M, Cadoux J, Broustet A: Gene dosage effect of human triosephosphate isomerase and glyceraldehyde-3-phosphate dehydrogenase in partial trisomy 12 pl 3 and trisomy $18 \mathrm{p}$. Hum Genet 45:63-69, 1978.

Sinet PM, Gresson J L, Couturier J, Colette L, Pricur M, Rethoré MO, Taillemite JL, Toudic O, Jerome H, Lejeune L: Localization probable de géne de la glutathion reductase (FC 1.6.4.2.) sur le bande 8p21. Ann Génét 20:13-17, 1977.

Taylor KM, Francke U, Brown MG, Gcorge DL, Kaufhold M: Inverted tandem ("mirror") duplications in human chromosomes: inv dup 8p, 4q, 22q. Am J Med Genet 1:3-19, 1977.

Yanagisawa S: Partial trisomy 8; further observation of a familial $\mathrm{C} / \mathrm{G}$ translocation chromosome identified by the Q-staining method. J Ment Defic Res 17:28-32, 1973.

Yanagisawa S, Hiraoka K: Familial $\mathrm{C} / \mathrm{G}$ translocation in three relatives associated with severe mental retardation, short stature, unusual dermatoglyphics and other malformations. J Ment Defic Res $15: 136-146,1971$. 